\title{
Identification and life history of aphids associated with chili pepper crops in southwestern Colombia
}

\author{
William Tálaga-Taquinas ${ }^{1,4}$, Clara-Inés Melo-Cerón ${ }^{2,4}$, Yorley-Beatriz Lagos-Álvarez ${ }^{1,4}$, \\ Diana N. Duque-Gamboa ${ }^{3,4}$, Nelson Toro-Perea, ${ }^{3,4}$ \& Maria R. Manzano, ${ }^{1,4, *}$
}

Edited by

Juan Carlos Salcedo-Reyes

(salcedo.juan@javeriana.edu.co)

1. Universidad Nacional de Colombia, Facultad de Ciencias Agropecuarias,

Departamento de Ciencias Agrícolas,

Grupo de Investigación Interacciones

Tritróficas, Palmira, Colombia,

Carrera 32 \# 12-00, Palmira, Valle,

Colombia, Postal code 763533.

2. Universidad Nacional de Colombia,

Facultad de Ciencias Agropecuarias,

Departamento de Ciencias Biológicas,

Grupo de Investigación Interacciones

Tritróficas, Palmira, Colombia,

Carrera 32 \# 12-00, Palmira, Valle,

Colombia, Postal code 763533.

3. Universidad del Valle, Facultad

de Ciencias Naturales y Exactas,

Departamento de Biología, Grupo

de Investigación en Estudios

Ecogenéticos y de Biología Molecular,

Calle 13 \# 100-00, edificio 320,

Cali, Colombia, Postal code 760032.

4. Universidad del Valle, Centro

de Investigación e Innovación en

Bioinformática y Fotónica CIBioFi,

Calle 13 \# 100-00, edificio 320 \#

1069, Cali, Colombia, Postal code

760032 .

*mrmanzanom@unal.edu.co

Received: 20-08-2019

Accepted: 17-04-2020

Published on line: 10-06-2020

\begin{abstract}
Viral diseases, transmitted by aphids, are the most limiting problems in chili pepper crops. Understanding the demographic features of these aphids, may thus assist the design of better disease control strategies in chili peppers. Aphid species found in chili pepper crops in southwestern Colombia were identified as Aphis gossypii Glover and Myzus persicae (Sulzer). An array of life-history parameters of both aphid species were investigated at $25{ }^{\circ} \mathrm{C} \pm 0.5,75 \pm 1.75 \%$ r.h., L12:D12, and LS 5-Light Storm in chili pepper crops. Both aphid populations consisted only of parthenogenetic females, showing a similar average development time-from the first nymphal instar to the post-reproductive adult-, female longevity, and daily average fertility values. The length of the reproductive period was higher for $M$. persicae. A. gossypii reached its adult state significantly faster than $M$. persicae. The intrinsic rate of population growth $\left(r_{m}\right)$ was lower for $M$. persicae (0.39) compared to $A$. gossypii (0.43). Results showed a potential for fast population growth in both species, which would enhance their role as virus vectors. The information acquired is essential to develop pest management initiatives for these two aphid species.
\end{abstract}

Keywords: Aphis gossypii, Barcoding, Capsicum, Myzus persicae, $r_{m}$ values.

\section{Introduction}

Chili pepper viral diseases, caused by Potyvirus, Cucumovirus, and Poleovirus, are transmitted by several aphid species (Hemiptera: Aphididae) [1] and severely affect crop production; losses may reach $100 \%$ depending on the level disease incidence. Worldwide, 16 aphid species have been specifically reported in chili pepper crops [2]. In Colombia, 3941 ha are cultivated with 
Citation: Tálaga-Taquinas W, Melo-Cerón CI, Lagos-Álvarez YB, Duque-Gamboa DN, Toro-Perea N, Manzano MR. Identification and life history of aphids associated with chili pepper crops in southwestern Colombia, Universitas Scientiarum, 25 (2): 175-200, 2020 doi: 10.11144/Javeriana.SC25-2.ialh

Funding:

Universidad Nacional de Colombia -Palmira campus and and Fondo CTeISistema General de Regalías.

Electronic supplementary material: Supp. 1

OPEN ACCESS of chili peppers, of which 167 are located in the department of Valle del Cauca (southwestern Colombia) [3]. A fraction of the product is destined to local consumption, and most of it is exported as chili paste. Local chili pepper producers spray insecticides to control both viral symptoms and aphids regardless of aphid species identity. The lack of species-related information on chili pepper aphids hinders the development of proper pest management plans [4].

A precise taxonomic identification of aphids, especially in the field, is challenging because of morphotypes with discreet morphometric differences within the same species [5] and chromatic variations unleashed by environmental stimuli [6] and intrinsic factors such as overpopulation or the type of host [7]. Molecular identification approaches, overcome the difficulties posed by morphological traits in telling aphid species apart. More precisely, the Cytochrome c Oxidase Subunit I (COI) gene region provides barcoding data complementing the morphologic identification of aphid species at any developmental stage $[4,8]$, namely by discriminating cryptic species [9], allowing the assignment of morphotypes of different development stages within a given species [10], and clarifying the confounding effect of host-related variation among aphid morphotypes [11].

Aphid populations can grow profusely because they exhibit cyclic parthenogenesis which combines sexuality and parthenogenesis, and, depending on crowding conditions or plant quality, they are capable of producing either winged or wingless parthenogenetic females [12]. However, in hot tropical and sub-tropical climates, aphids usually reproduce by thelytokous parthenogenesis [2], resulting in fast population growth. Besides, aphid populations entail overlapping generations, parental groups, as well as their older descendants contribute to population increase [13]. One way to measure the potential population growth of an aphid species is via life tables. These constitute crucial tools to comprehend population dynamics, estimate the insects' potential and reproductive growth parameters [14], which, in turn, influence how aphid-borne viruses spread [15].

To broaden the knowledge about aphids in chili pepper crops in southwestern Colombia, we first identified the aphid species occurring in these crops, using morphological and molecular tools. Next, we established and compared some demographic and life history traits of the aphid species, in the hopes of understanding their impact on aphid-borne virus transmission in chili pepper crops. The results of this study can be applied to develop suitable aphid management plans in chili peppers. 


\section{Materials and Methods}

Study site

Aphids were sampled in commercial chili pepper crops, including tabasco pepper (Capsicum frutescens), cayenne pepper (Capsicum annuum), jalapeño pepper (Capsicum annuum), and habanero pepper (Capsicum chinense) in the valley of the Cauca River (department of Valle del Cauca) Colombia. The crops were located in ten municipalities, with altitudes between 689 and 1295 meters above sea level, comprising tropical dry forests in alluvial foothills and humid forests in fluvial-gravitational m ountains. The region has an average temperature of $23.3 \pm 6^{\circ} \mathrm{C}$, relative humidity of $79 \pm 2.4 \%$, rainfall of $1313 \mathrm{~mm} /$ year, and wind speed of $1.5 \mathrm{~m} / \mathrm{s}$. A total of 58 hectares of chili pepper crops were sampled in 29 commercial farms from 18 localities that cultivate tabasco pepper ( 15 farms, $39 \mathrm{ha}$ ), habanero pepper ( 8 farms, $9 \mathrm{ha}$ ), cayenne pepper (4 farms, $7 \mathrm{ha}$ ), and jalapeño pepper ( 2 farms, $3 \mathrm{ha}$ ), from October 2015 to October 2017.

\section{Aphid sampling, preservation, and identification}

Chili pepper plants of more than 16 months of age were chosen randomly and examined for two hours. Both winged and wingless aphid nymphs and adults were collected. For molecular identification, aphids were deposited immediately in containers with $96 \%$ alcohol and stored at $-20{ }^{\circ} \mathrm{C}$. For morphologic identification, adults and nymphs were placed alive in plastic boxes $(23 \mathrm{~cm} \times 17 \mathrm{~cm} \times 12 \mathrm{~cm})$ with chili pepper leaves, covered with mesh and transported to the laboratory. Insects for morphological identification were sacrificed in water at $80{ }^{\circ} \mathrm{C}$ (to prevent post-mortem aphid melanization) and kept in a $70 \%$ alcohol solution. Subsequently, they were sorted by morphotype and preserved in microscope plates following the modified protocol of Blackman and Eastop [16]. The taxonomic identification was carried out using the keys of Blackman and Eastop [16, 2]. Aphid identification was confirmed by experts at the Entomological Museum of the Universidad Nacional de Colombia in Bogotá, UNAB.

\section{Molecular identification using DNA barcoding}

COI gene sequences: To obtain the COI gene sequences, DNA was extracted from 40 aphids of different chili pepper crops (two of $C$. frutescens and two of C. annuum), and from 39 aphids representing the different morphotypes under mesh house rearing. DNA was extracted from the entire body of each aphid with the commercial animal tissue kit from QIAGEN, following the manufacturer's recommendations. DNA 
quantifications were done with a NanoDrop 2000 spectrophotometer. COI amplification was carried out with the primers described by Folmer et al. [17], LCO1490 (5' ggtcaacaaatcataaagatattgg-3') and HCO2198 (5'-taaacttcagggtgaccaaaaaatca-3'), under the amplification conditions used by Duque-Gamboa et al. [18]. Amplified products were displayed in agarose gels and sequenced at MACROGEN (Seoul, South Korea). The sequence files obtained were edited and aligned using MEGA6 [19].

Molecular identification of aphid species: Species recognition was carried out employing the neighbor-joining (N-J) grouping method, calculating genetic distances between haplotypes, and comparing the sequences obtained with those reported in public databases [20, 21]. The N-J analysis under the Kimura's two-parameter model (K2P) and 1000 bootstrap replicates were performed with the purpose of discriminating haplotype clusters and genetic distances among pairs of haplotypes within every cluster. Sequences showing genetic intra-group distances below $2 \%$ were assigned to the same taxonomic unit. Interspecific genetic distances were estimated among clusters. All DNA sequence analyses were done with the software MEGA6 [19]. Finally, the sequences of different taxonomic units were compared with the ones available in the BOLD public databases (Barcode of Life Data Systems) and NCBI (National Center for Biotechnology Information), which allowed for species identification $[22,20]$. Each reared aphid stage and the morphotypes found due to polychromy, during their immature development, were identified via COI gene sequencing. Three specimens were used per morphological form and color, adding to $33 \mathrm{COI}$ gene sequences for $A$. gossypii. Individuals of $M$. persicae showed a stable coloration pattern during their development period and six COI gene sequences were obtained.

\section{Aphid life history traits}

Aphids were reared on jalapeño pepper plants placed inside mesh and aluminum boxes $(60 \mathrm{~cm} \times 60 \mathrm{~cm} \times 60 \mathrm{~cm})$ under screenhouse conditions (average values of $24.9^{\circ} \mathrm{C} \pm 4.1$ and $87.9 \%$ r.h \pm 9.2 ). For life history trait experiments, aphids were fed tabasco pepper leaflets kept fresh in plastic Petri dishes $(9.0 \mathrm{~cm} \times 1.6 \mathrm{~cm})$ with agar $(35 \mathrm{ml}$ of an agar medium and $10 \%$ water) and under controlled conditions $\left(25^{\circ} \mathrm{C} \pm 0.5,75 \pm 1.75 \%\right.$ r.h., photoperiod L12:D12, and LS 5-Light Storm) in a climatic chamber (Humidity Panasonic Model MLR-351H-PA ${ }^{\circledR}$.

\section{Duration of the immature and adult stages}

To establish the duration of aphid immature and adult stages, newborn nymphs were observed daily until they completed their development. The 
presence of the exuvia marked the duration of the nymphal instar. Aphid development was divided into four stages: i) presence of immature stages, ii) presence of pre-reproductive adults, iii) presence of reproductive adults, and iv) presence of post-reproductive adults. The evaluated time lapse for all stages in every identified aphid species was recorded in days.

Development time, survival rate, and proportion of females

Adult females of each aphid species ( $\mathrm{n}=148$ for $A$. gossypii and $\mathrm{n}=150$ for $M$. persicae) were placed individually in Petri dishes with agar on chili pepper leaflets. Nymphs were fed with new chili pepper leaves every three days and females were withdrawn as soon as they delivered their first nymph. Development time (days) was established from the first nymphal stage until the emerged female delivered the first descendant nymph (pre-reproductive period). Survival rate of immature individuals and proportion of females of each aphid species were recorded.

\section{Aphid longevity and reproduction}

Newly emerged adult females were moved to Petri dishes with agar on chili pepper leaflets. To determine longevity and fertility values, the number of nymphs produced by each female ( $\mathrm{n}=45$ for $A$. gossypii and $\mathrm{n}=49$ for $M$. persicae) was registered every 24 hours until the female died.

\section{Aphid demographic traits}

Development time and survival of immature individuals were combined with experimental reproduction data to create life tables " $l_{x}-m_{x}$ " and calculate aphid demographic traits. The following parameters were calculated for each species: net reproductive rate $\left(\mathrm{R}_{0}\right.$, is the number of daughters replacing an average female in the course of a generation), and generational time ( $T$, describes the time between each generation). To calculate the intrinsic rate of population growth $\left(r_{m}\right)$ per species, Eq. 1 was used [23]:

$$
\sum \exp \left(-r_{m} x\right) l_{x} m_{x}=1
$$

Where: $x=$ age (days), $l_{x}=$ female age-specific survival, and $m_{x}=$ proportion of female offspring of a female at age x. Following Carey [23], the pivotal female age was used, i.e. $x+0.5$ to calculate the $r_{m}$ value.

\section{Statistical analysis}

Average values were accompanied with standard errors $( \pm \mathrm{SE})$. The normality of data was checked using the Shapiro-Wilk test. Differences among species 
concerning longevity, fertility, development time, and length of each development stage were compared via the Student's t-test using the Software $\mathrm{R}$ v3.3.4 ${ }^{\circledR}[24]$. The Chi square test was used to compare the number of aphids surviving to adulthood within aphid species.

\section{Results}

\section{Taxonomic identification of chili pepper aphids}

Two aphid species were collected in the chili pepper crops assessed in 29 commercial farms from 18 localities in ten municipalities of Colombia. The two species were Aphis gossypii Glover, 1877 and Myzus persicae (Sulzer, 1776). Out of the 29 locations sampled, aphids were found at 20 sites, with A. gossypii detected at 19 sites (65.5\%), M. persicae at 5 sites $(17.2 \%$,) and both species at 4 sites (13.8\%). Aphis gossypii dwelled mostly in tabasco pepper $(66.7 \%)$, followed by cayenne pepper (14.3\%), jalapeño pepper ( $9.5 \%)$, and habanero pepper $(9.5 \%)$. Likewise, the main host for $M$. persicae was tabasco pepper ( $80 \%)$, followed by jalapeño pepper ( $20 \%$ ). The distribution of both aphid species in the geographic valley of the Cauca River (southwestern Colombia) in all chili pepper species is shown in Fig. 1 and expanded in Suppl. 1.

\section{Identification of aphids with DNA barcoding}

COI gene sequences from 40 aphids, collected in jalapeño, habanero, tabasco, and cayenne chili pepper crops from different localities, were obtained. The $\mathrm{N}-\mathrm{J}$ analysis on the COI sequences produced two distinct groups (Fig. 2). The genetic distance within every cluster was $0 \%$, revealing the existence of a unique haplotype in each group. Haplotypes were deposited into the GenBank under the unique accession codes MH203408 for A. gossypii and MH203409 for M. persicae.

The distance between clusters was $10 \%$, which matches interspecific differentiation. When comparing these haplotypes with those available in public databases, only matches with $100 \%$ similarity and coverage were considered to identify sequences. Thus, sequences in clade A agreed with the species $A$. gossypii, whereas sequences in clade $\mathrm{B}$ belonged to the species M. persicae (Fig. 2). Aphids reared under laboratory conditions matched the GenBank sequences for A. gossypii and M. persicae, and corresponded to the morphological identification of each development stage of both species (Fig. 3). Additionally, the Barcoding technique established that yellow, yellow-light green, yellow-dark green, and black/black-green aphids observed in the field and in the laboratory are phenotypical variations of the species A. gossypii. 


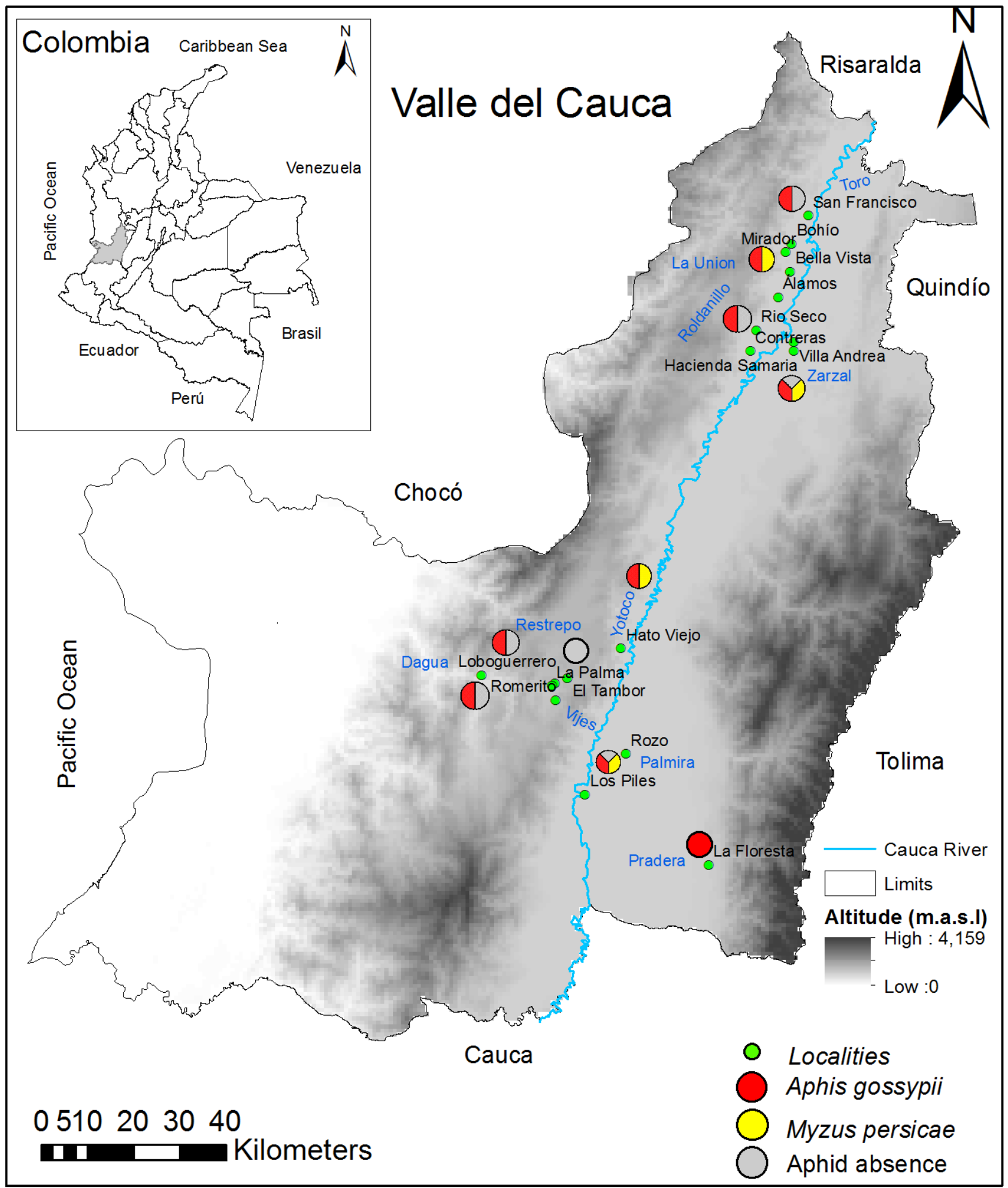

Figure 1. Distribution map of aphid species (presence - absence) in the surveyed areas. Aphis gossypii (red circle), Myzus persicae (yellow circle), and absence aphid (gray circle). Names of the municipalities are indicated in blue color and those of sampling locations in green color. 


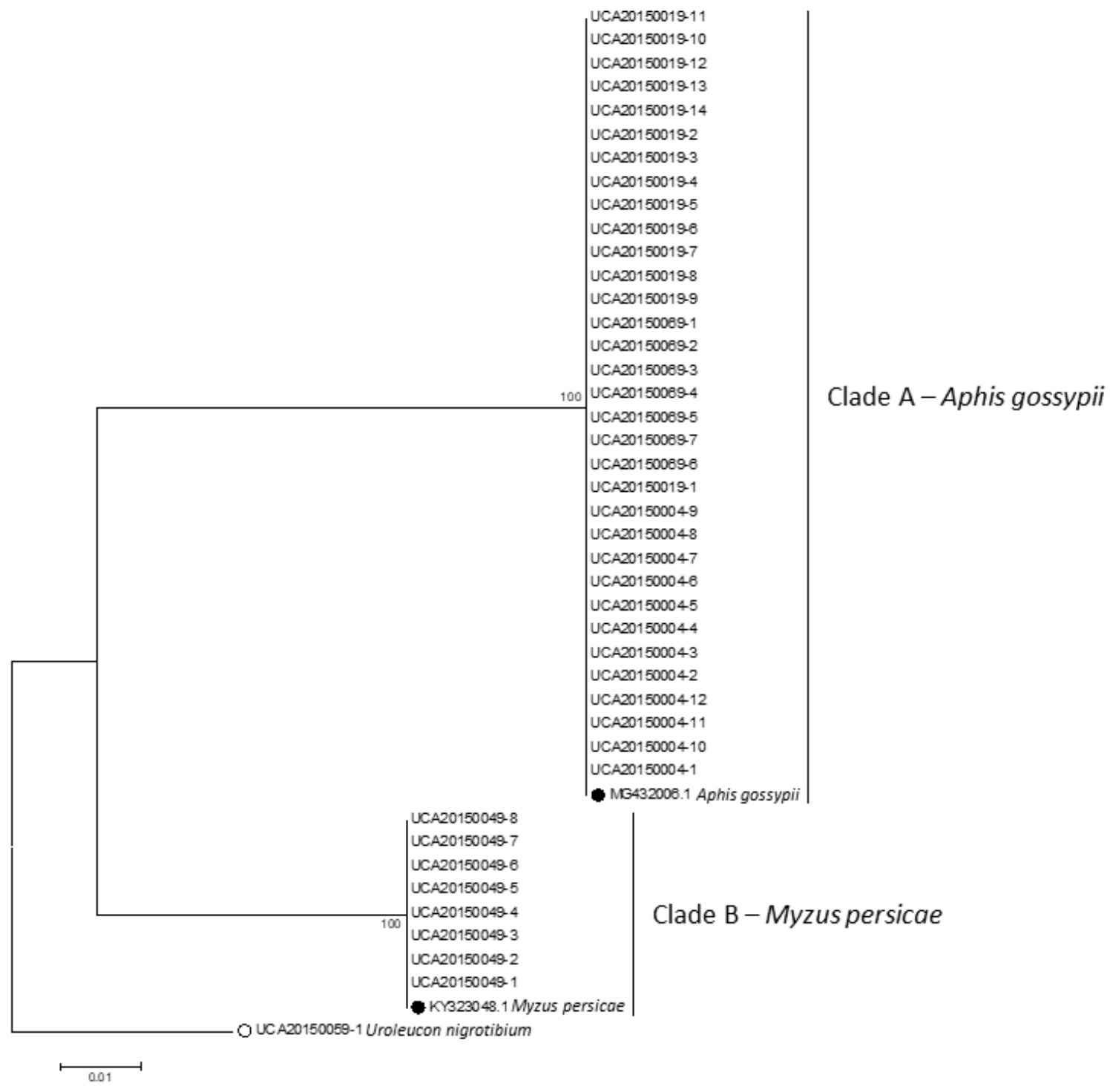

Figure 2. Sequences grouping analysis of Aphididae employing the N-J (1 000 bootstraps) method, under a K2P model. The Black circles indicate the sequences obtained from GenBank exhibiting $100 \%$ identity with the Aphididae individuals sampled in Capsicum spp. The white circle indicates the external group used in the analysis.

Life history traits of $M$. persicae and A. gossypii

Polychromia was observed in Aphis gossypii, aphids of these species exhibited yellow, yellow-light green, yellow-dark green, black and black-green body colors during their development. Myzus persicae aphids showed all a light-yellow color during its development. Both $M$. persicae and A. gossypii went through four nymphal instars (Stage 1 - Stage 4) with an average length of 1.4 days per stage for $M$. persicae and of 1.1 for $A$. gossypii (Table 1). 


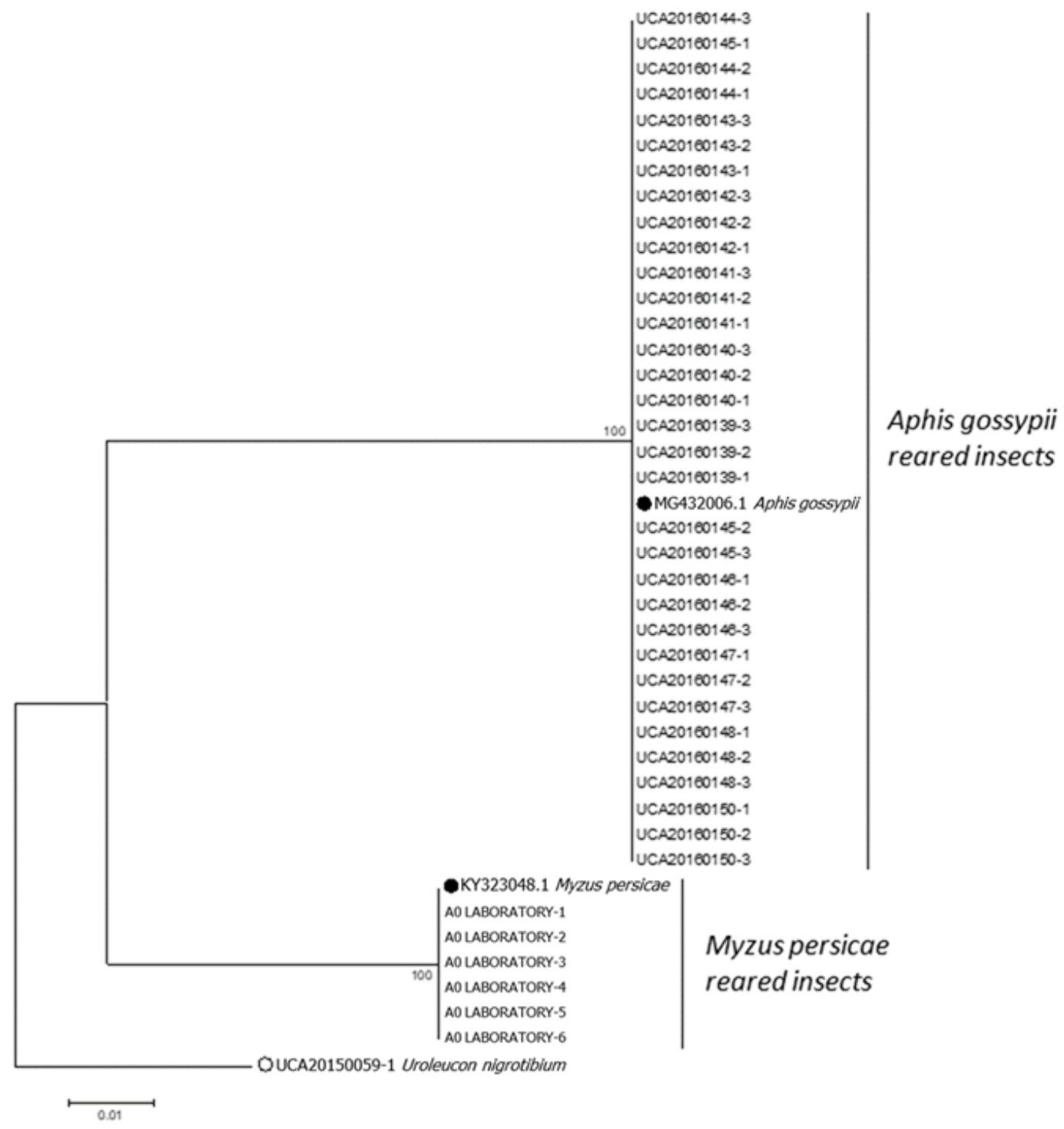

Figure 3. Grouping analysis employing the N-J (1 000 bootstrap) method, under a K2P model of aphid sequences raised in the laboratory. The black circles indicate the obtained GenBank exhibiting 100.

A difference regarding the duration of each of the nymphal instars was found between $A$. gossypii and $M$. persicae (Table 1): Stage $1(\mathrm{t}=-16.09$, d. $\mathrm{f}=296$, $\mathrm{P}<0.001)$, Stage $2(\mathrm{t}=-5.42$, d. $\mathrm{f}=296, \mathrm{P}<0.001)$, Stage $3(\mathrm{t}=-11.04$, d. $\mathrm{f}=$ 296, $\mathrm{P}<0.001)$ and Stage $4(\mathrm{t}=-16.89$, d.f $=296, \mathrm{P}<0.001)$. All phases lasted longer in $M$. persicae than in A. gossypii (Table 1).

Only females were obtained in the adult stage, confirming reproduction by thelytokous parthenogenesis in both aphid species. The adult stage exhibited three reproductive phases. The first was the pre-reproductive phase, which 
Table 1. Average development length (days $\pm \mathrm{SE}$ ) within the different nymphal stages of Aphis gossypii $(\mathrm{n}=148)$ and Myzus persicae $(\mathrm{n}=150)$ under controlled conditions $\left(25^{\circ} \mathrm{C} \pm 0.5,75 \pm 1.75 \%\right.$ r.h., and photoperiod L12:D12, LS 5-Light Storm) in cayenne pepper (Capsicum annuum). Asterisks indicate significant statistical differences between species means $(\mathrm{P}<0.001)$.

\begin{tabular}{lcccc}
\multicolumn{1}{c}{ Species } & Stage 1 & Stage 2 & Stage 3 & Stage 4 \\
\hline M. persicae & $1.50^{*} \pm 0.016$ & $1.24^{*} \pm 0.019$ & $1.40^{*} \pm 0.017$ & $1.50^{*} \pm 0.019$ \\
\hline A. gossypii & $1.14 \pm 0.002$ & $1.09 \pm 0.001$ & $1.10 \pm 0.001$ & $1.10 \pm 0.001$ \\
$\mathrm{t}$ & -16.09 & -5.42 & -11.04 & -16.89 \\
\hline d.f & 296 & 296 & 296 & 296 \\
\hline $\mathrm{P}$ & $<0.001$ & $<0.001$ & $<0.001$ & $<0.001$ \\
\hline
\end{tabular}

was significantly longer $(\mathrm{t}=-6.78$, d. $\mathrm{f}=92, \mathrm{P}<0.001)$ in $M$. persicae $(0.90$ days $\pm 0.016, \mathrm{n}=49$ ) compared to $A$. gossypii ( 0.73 days $\pm 0.072, \mathrm{n}=45)$. The second was the reproductive phase, being also longer $(\mathrm{t}=-8.65$, d.f $=92$, $\mathrm{P}<0.001)$ in $M$. persicae (16.98 days $\pm 0.037, \mathrm{n}=49$ ) compared to $A$. gossypii $(12.64 \pm 0.320, \mathrm{n}=45)$. The post-reproductive phase; however, was longer $(\mathrm{t}=$ 12.02, d.f $=92, \mathrm{P}<0.001)$ in A. gossypii (7.95 days $\pm 0.072, \mathrm{n}=45)$ compared to $M$. persicae $(1.32 \pm 0.017, \mathrm{n}=49$, Table 2$)$. Although inter-specific, immature to post-reproductive stage, length differences were observed, these were not statistically significant $(\mathrm{t}=-0.28$, d.f $=92, \mathrm{P}=0.774 ; M$. persicae: $24.84 \pm 0.063, \mathrm{n}=49$ and $A$. gossypii: 25.75 days $\pm 1.710, \mathrm{n}=45$; Table 2 ). Concerning reproduction, $A$. gossypii aphids devoted half their lifespan to reproduction, and $M$. persicae devoted slightly more time to the same activity.

The length of the nymphal period was significantly longer $(\mathrm{t}=-28.41$, d.f $=296, \mathrm{P}<0.001)$ in $M$. persicae $(5.64 \pm 0.071, \mathrm{n}=150)$ compared to A. gossypii (4.43 $\pm 0.014, \mathrm{n}=148$, Table 2). Survival from N1 to adult was significantly higher $\left(\mathrm{X}^{2}=8.416 ; \mathrm{df}=1 ; \mathrm{P}=0.004\right)$ for $M$. persicae $(100 \%$, $\mathrm{n}=49$ ) compared to $A$. gossypii $(93.2 \%, \mathrm{n}=45)$. Only daughters were obtained in both species. 
Table 2. Average duration of the nymphal stage of Aphis gossypii $(\mathrm{n}=148)$ and Myzus persicae $(\mathrm{n}=150)$, the adult stage (pre-reproductive, reproductive and post-reproductive) and the nymph-adult period (days $\pm \mathrm{SE}$ ) of Aphis gossypii ( $\mathrm{n}=45)$ and Myzus persicae $(\mathrm{n}=49)$ under controlled conditions $\left(25^{\circ} \mathrm{C}\right.$ \pm 0.5, $75 \pm 1.75 \%$ r.h., photoperiod L12:D12, and LS 5-Light Storm) in cayenne pepper (Capsicum annuum). Asterisks indicate significant statistical differences between species means $(\mathrm{P}<0.001)$.

\begin{tabular}{|c|c|c|c|c|c|}
\hline 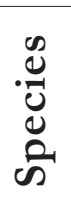 & $\begin{array}{l}\text { Nymph- } \\
\text { Adult }\end{array}$ & $\begin{array}{l}\text { Pre- } \\
\text { reproductive }\end{array}$ & Reproductive & $\begin{array}{l}\text { Post- } \\
\text { reproductive }\end{array}$ & $\begin{array}{c}\text { Nymph } \\
\text { Post- } \\
\text { reproductive } \\
\text { adult }\end{array}$ \\
\hline 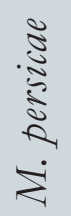 & $5.64 * \pm 0.071$ & $0.90 * \pm 0.016$ & $16.98 * \pm 0.037$ & $1.32 * \pm 0.017$ & $24.84 * \pm 0.063$ \\
\hline 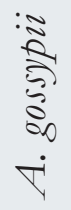 & $4.43 \pm 0.014$ & $0.73 \pm 0.072$ & $12.64 \pm 0.320$ & $7.95 \pm 0.072$ & $25.75 \pm 1.710$ \\
\hline$\leftarrow$ & -28.41 & -6.78 & -8.65 & 12.02 & -0.28 \\
\hline 峞 & 296 & 92 & 92 & 92 & 92 \\
\hline A & $<0.001$ & $<0.001$ & $<0.001$ & $<0.001$ & 0.774 \\
\hline
\end{tabular}

The average longevity in female adults was similar between A. gossypii (25.9 \pm 0.49 days) and $M$. persicae $(25.0 \pm 0.42$ days; Table 3$)$. Daily average fertility was also similar in both species, i.e. $3.9 \pm 0.60$ nymphs/female for A. gossypii and $3.4 \pm 0.41$ nymphs/female for $M$. persicae. In addition, the overall average fertility was similar $(\mathrm{t}=-1.89, \mathrm{df}=92, \mathrm{P}=0.060)$ between $M$. persicae (71.28 \pm 1.876 nymphs) and A. gossypii (65.55 \pm 2.310 nymphs; Table 3).

Fig. 4A shows survival $\left(l_{x}\right)$ and fertility $\left(m_{x}\right)$ curves for $M$. persicae. These females started to reproduce when they were two days old and delivered an average of four nymphs per day. They reached maximum fertility at six days 
Table 3. Average longevity (days $\pm \mathrm{SE}$ ) and fertility (nymphs/female $\pm \mathrm{SE}$ ) of Aphis gossypii $(\mathrm{n}=45)$ and Myzus persicae $(\mathrm{n}=49)$ in cayenne pepper (Capsicum annuum) under controlled conditions $\left(25^{\circ} \mathrm{C} \pm 0.5,75 \pm 1.75 \%\right.$ r.h., photoperiod L12:D12, and LS 5-Light Storm).

\section{Parameter}

Aphids species

\begin{tabular}{|c|c|c|c|c|c|}
\hline & A. gossypii & M. persicae & & & \\
\hline Average longevity $\pm \mathrm{SE}$ (days) & $25.9 \pm 0.49$ & $25.0 \pm 0.42$ & 1.25 & 88 & 0.209 \\
\hline Range & $20.1-33.1$ & $19.7-30.7$ & & & \\
\hline $\begin{array}{l}\text { Average fertility } \pm \text { SE } \\
\text { (daughters/female) }\end{array}$ & $65.55 \pm 2.31$ & $71.28 \pm 1.87$ & -1.91 & 98 & $0.048^{*}$ \\
\hline Range & $30-90$ & $44-99$ & & & \\
\hline $\begin{array}{l}\text { Daily average fertility } \pm \text { SE } \\
\text { (daughters/female) }\end{array}$ & $3.9 \pm 0.60$ & $3.4 \pm 0.40$ & 0.62 & 37 & 0.534 \\
\hline Range & $0.1-6.8$ & $0.3-6.1$ & & & \\
\hline
\end{tabular}

old (six nymphs on average per day), and when they were 12 days old, fertility decreased steadily. No female died during the first 14 days assessed. In fig. 4B, survival $\left(l_{x}\right)$ and fertility $\left(m_{x}\right)$ curves for $A$. gossypii are displayed. Females started to reproduce when they were one-day old and delivered an average of one nymph per day, reaching a maximum fertility ( 7 nymphs on average per day) when they were five days old. After 11 days old, fertility decreased rapidly. No female died during the first 11 days of evaluation.

Demographic traits of $M$. persicae and A. gossypii

The intrinsic rates of population growth $\left(r_{m}\right)$ for $M$. persicae and A. gossypii were 0.39 and 0.43 , respectively (see Eq. 1 ). Generational time $(T)$ was higher for $M$. persicae (13.8 days) compared to A. gossypii (11.7 days) and the net reproductive rate $\left(\mathrm{R}_{0}\right)$ was 65.5 for $A$. gossypii and higher for $M$. persicae, with 72.8 . 
A

$\multimap-$ Survival $-\cdot \bullet-$ Fertility

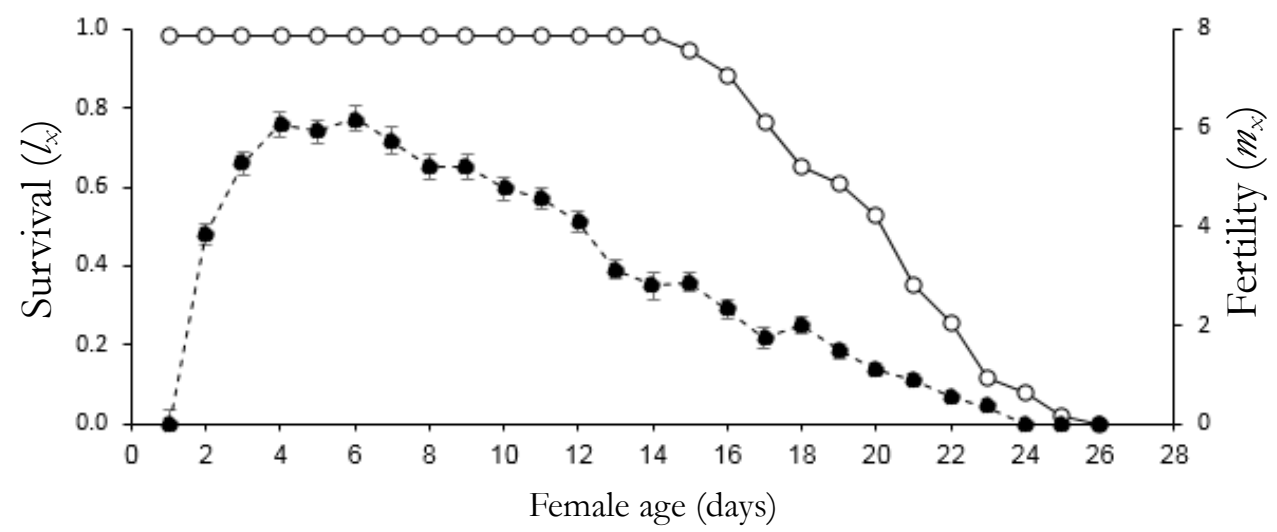

B $\multimap$ Survival $--\bullet$ - Fertility

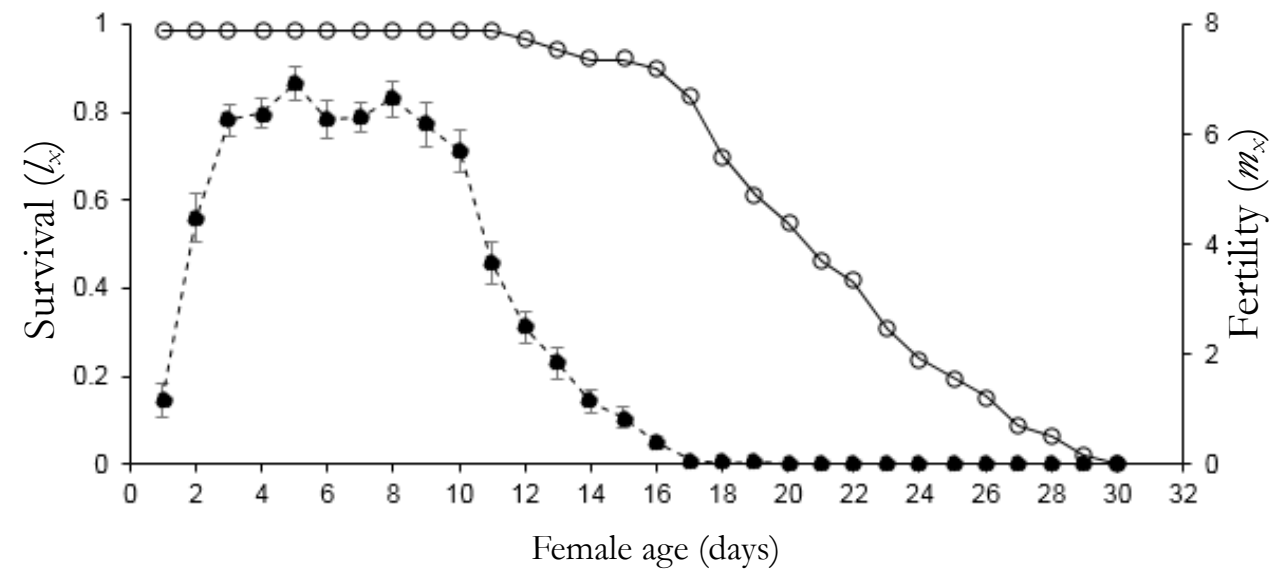

Figure 4. Survival $\left(l_{x}\right)$ is expressed as the number of live females and fertility $\left(m_{x}\right)$ is expressed as the number of nymphs per female; (A) Myzus persicae ( $\mathrm{n}=4$ 9) and (B) Aphis gossypii ( $\mathrm{n}=45)$ on Capsicum annuum plants (cayenne pepper) under controlled conditions $\left(25^{\circ} \mathrm{C} \pm 0.5,75 \pm 1.75 \%\right.$ r.h., and photoperiod L12:D12, LS 5-Light Storm). Error bars indicate \pm standard error of the mean.

\section{Discussion}

Globally, sixteen aphid species have been reported in chili pepper (Capsicum spp.) crops [2]. Our research indicated that the aphid pest community associated with chili pepper crops in southwestern Colombia is much less diverse than expected [15]. The only aphid species found were 
$M$. persicae and $A$. gossypii, the latter being the one with the highest incidence. Both species have previously been reported in chili pepper crops [25, 26]. Specifically, in the tropics, a low aphid species diversity is a common situation due to the short period in which aphids can survive without food. Three related factors contribute to this situation, (i) aphids must meet the high food demands of the embryos developing within them, (ii) they exhibit a high degree of host specificity, and (iii) they are not efficient in locating host plants [27]. Furthermore, our results show that the lack of genetic variation within $A$. gossypii and $M$. persicae could be a consequence of the observed situation; females were genetically identical since they reproduced exclusively by parthenogenesis.

The DNA barcoding technique confirmed and supported the morphological identification of $A$. gossypii and $M$. persicae $[4,10]$. Barcoding was useful to overcome species diagnostic difficulties in aphids. These difficulties are due to loss of useful taxonomical characters, phenotypic plasticity related to host plant interactions, stress, morphological particularities within each development stage, as well as polychromy [11]. In fact, most of these were observed specifically in $A$. gossypii.

Climate variables, especially temperature, influence the demographic traits of aphids [28]. The highest incidence of $A$. gossypii, and, concomitantly, the lowest incidence of $M$. persicae in the assessed chili pepper crops $\left(18.6-30.1^{\circ} \mathrm{C}\right.$ range) can be partially explained by the adaptation capacity of each species to tropical temperature. $M$. persicae is greatly affected by high temperatures, with an optimal development between $15-20{ }^{\circ} \mathrm{C}$ [29], thus being mostly found in temperate regions [30]. On the contrary, A. gossypii, has its best performance between $26-30^{\circ} \mathrm{C}$ [31] and prefers tropical zones [32]. Nevertheless, the average immature development time (from the first nymphal stage up to the post-reproductive adult) was 25.7 days for $A$. gossypi and 24.8 days for $M$. persicae. These values were similar in our study, since temperature [33] and host plant conditions [34] affect the length of the development of aphids. Both species showed four nymphal stages, as found by Dixon et al. [27], lasting between 1.1-1.5 days, on average. This range matches what has previously been reported in chili pepper crop aphids [35].

The development time from nymph 1 (Stage 1) to adult was short for both species ( $<6$ days). This makes it possible to obtain females rapidly, which will start to reproduce the day after emerging. These features, as well as their reproduction via obliged thelytoky parthenogenesis, are common in tropical regions [12], and allow both species to develop larger populations in a short amount of time. Our results show that their descendants are clones, with adaptive characteristics for local environmental conditions [36]. 
Both species delivered around three or four nymphs per day although the length of the reproductive period was significantly higher for $M$. persicae, than for $A$. gossypii. This finding clashes with the idea of a less adapted $M$. persicae to hot climates; namely this species showing higher fertility and longevity at temperatures below $15^{\circ} \mathrm{C}$ [37]. Nevertheless, the trait values we observed seem to reflect the adaptation of the aphid to chili pepper crops. For instance, a maximum overall average fertility of 62.7 individuals at $25 \pm 1{ }^{\circ} \mathrm{C}$ [25] has been reported in bell pepper (C. annuum) aphids, which is a lower value than what we observed in our work.

The post-reproductive period was shorter for $M$. persicae ( $<2$ days), indicating that females of this species die quickly after they reproduce [38], whereas in $A$. gossypii we observed a longer post-reproductive period. $M$. persicae compensates its shorter survival time with a broader reproduction period that could be interpreted as an adaptive advantage in this species. These biological differences can influence virus transmission dynamics in the assessed chili pepper crops [39], given that $A$. gossypii stays and feeds longer in the crop, thus having more chance to spreading the virus.

Population parameters needed to create life tables for aphids are highly influenced by the host plant $[34,14]$ and by the environmental temperature [31]. In fact, the Capsicum $r_{m}$ values found in our study are in the range reported by other authors. In C. frutescens and C. annuum, the $r_{m}$ values of 0.27 and 0.48 for $A$. gossypii were reported by Singh and Singh [40] and Satar et al. [41], respectively. For $M$. persicae in C. annuum, $r_{m}$ values of 0.31 [29], $0.33[25]$ and $0.41[41]$ were reported.

According to our results, net reproductive rate $\left(R_{o}\right)$ and generational time $(T)$ were superior in $M$. persicae (72.8 and 13.8, respectively) than in $A$. gossypii (65.5 and 11.7, respectively). The $R_{o}$ value found in $A$. gossypii is superior to the one reported in cotton crops, i.e. 21.7 and 24.8 at a temperature of 27.5 $\pm 1{ }^{\circ} \mathrm{C}[34]$ and 40 at a temperature of $23^{\circ} \mathrm{C}$ [42]. This depicts, once again, the adaptative capacity of $A$. gossypii to chili pepper crops.

Biological and demographic features show the adaptation of both aphid species to Capsicum spp., although $A$. gossypii is more frequent and abundant. Therefore, future studies are needed to establish if this asymmetry is a product of direct competitive interactions in these crops. Precisely, Denno et al. [43] mention the following facts as competition triggers between the two species: both are sap feeders, live in aggregates, and inhabit managed environments (i.e. agroecosystems). On the other hand, top-down cascades represented by the diversity of the natural enemies of aphids (for instance, Coccinellid beetles) 
[44] found in chili pepper crops and their companion plants (unpublished data) could be shaping the incidence of the aphid species [45]. In addition to these trophic cascades, the insecticides sprayed in the crops sampled could have affected the incidence of aphids, either decreasing their presence [46] or favoring it through the elimination of their natural enemies [47].

Although the presence of aphids causes demonstrable yield losses in several crops [48], for chili pepper crops, the greatest concern is the economic loss caused by the viruses transmitted by both aphid species. These viruses, transmitted through the stylet when feeding, appear in a non-persistent manner (unpublished data). The higher population growth of $A$. gossypii, a consequence of better adaptation to tropical climates [32] than $M$. persicae [37], could be reflected in a larger virus s pread. However, our demographic results for $M$. persicae suggest that this species could be adapting to warm climates.

\section{Conclusions}

A. gossypii and $M$. persicae are currently the only aphid species present in Capsicum spp. crops in southwestern Colombia. A. gossypii has a higher incidence and shows sharp polychromy during its development.

Both aphid species reproduce via thelytoky parthenogenesis combined with a short immature development phase (less than 6 days), which allows them to produce large populations in a short period. Females live between 25-26 days, showing an average daily fertility of 3-4 daughters, although $M$. persicae shows a longer reproductive period.

The intrinsic rate of natural growth $r_{m}$ was lower in $M$. persicae (0.39) compared to $A$. gossypii (0.43). Results suggest that $A$. gossypii and $M$. persicae are adapted to chili pepper crops and their high fertility, high survival, and short development time favor the function of both species on virus dispersion. Their role as virus vectors must be clarified for both species in Capsicum crops.

\section{Acknowledgements}

This work was funded by grants of Universidad Nacional de Colombia -Palmira campus- (HERMES 35892, HERMES 36866, HERMES 31256 and HERMES 39271) and Fondo CTeI-Sistema General de Regalías (BPIN 2013000100007). 
We thank Hugo Restrepo \& Cia. S.A. for aiding during the collection of research samples in the chili pepper crops. We thank Francisco Serna and Ronald Simbaqueba at the Agronomy Museum of Universidad Nacional de Colombia UNAB for aphid species confirmation. We acknowledge especially the two anonymous reviewers for their valuable comments to our manuscript.

\section{References}

[1] Kenyon L, Kumar S, Tsai WS, Hughes JA. Virus diseases of peppers (Capsicum spp.) and their control. In: Loebenstein, G. \& Nikolaos, K., eds. Advances in Virus Research, Elsevier, Amsterdam. pp. 297-354, 2014.

doi: 10.1016/B978-0-12-801246-8.00006-8

[2] Blackman RL, Eastop VF. Aphids on the world's herbaceous plants and shrubs. 1st ed. John Wiley and Sons Ltd, London, UK, 2006.

[3] FAO (Food and Agriculture Organization). Online statistical database: Production. FAOSTAT, [2016-11-06].

Retrieved from

http://faostat3.fao.org/download/FB/*/E

[4] Foottit RG, Maw HEL, von Dohlen CD, Hebert PDN. Species identification of aphids (Insecta: Hemiptera: Aphididae) through DNA barcodes, Molecular Ecology Resources, 8: 1189-1201, 2008. doi: 10.1111/j.1755-0998.2008.02297.x

[5] Jalalizand AR, Mirhendi H, Karimi A, Modaresi M, Mahmoodi E. Morphological and molecular identification aphids of rosae, APCBEE Procedia, 4: 12-15, 2012

doi: 10.1016/j.apcbee.2012.11.003

[6] Tsuchida T. Molecular basis and ecological relevance of aphid body colors, Current Opinion in Insect Science, 17: 74-80, 2016.

doi: 10.1016/j.cois.2016.07.005

[7] Blackman RL, Eastop VF. Taxonomic Issues. In: van Emden H. F. \& Harrington R., eds. Aphids as Crop Pests. CABI, London, pp. 1-29, 2007.

[8] Armstrong KF, Ball SL. DNA barcodes for biosecurity: invasive species identification, Philosophical Transactions of The Royal Society B Biological Sciences, 360: 1813-1823, 2005.

doi: $10.1098 /$ rstb.2005.1713 
[9] Piffaretti J, Vanlerberghe-Masutti F, Tayeh A, Clamens AL, D'Acier AC, Jousselin E. Molecular phylogeny reveals the existence of two sibling species in the aphid pest Brachycaudus helichrysi (Hemiptera: Aphididae), Zoologica Scripta, 41: 266-280, 2012.

doi: 10.1111/j.1463-6409.2012.00531.x

[10] Miller GL, \& Foottit RG. The taxonomy of crop pests: The aphids. In: Foottit R, Adler P. eds., Insect Biodiversity: Science and Society. Blackwell Publishing, Oxford. pp. 463-473, 2009.

doi: 10.1002/9781444308211.ch20

[11] Lokeshwari D, Kumar NKK, Manjunatha H. Color polymorphism does not affect species diagnosis of the melon aphid, Aphis gossypii (Hemiptera: Aphididae), Florida Entomologist, 97: 1199-1207, 2014.

doi: 10.1653/024.097.0327

[12] Simon J-C, Peccoud J. Rapid evolution of aphid pests in agricultural environments, Current Opinion in Insect Science, 26: 17-24, 2018.

doi: 10.1016/j.cois.2017.12.009

[13] Kindlmann P, Dixon AF. Modelling population dynamics of aphids and their natural enemies. In Kindlmann P, Dixon AF, Michaud J., eds. Aphid Biodiversity Under Environmental Change, Springer, Dordrecht. pp.1-20, 2010.

doi: 10.1007/978-90-481-8601-3_1

[14] Hosseini-Tabesh B, Sahragard A, Karimi-Malati A. A laboratory and field condition comparison of life table parameters of Aphis gossypii Glover (Hemiptera: Aphididae), Journal of Plant Protection Research, 55: 1-7, 2015.

doi: 10.1515/jppr-2015-0001

[15] McDonald SA, Halbert SE, Tolin SA, Nault BA. Seasonal abundance and diversity of aphids (Homoptera: Aphididae) in a pepper production region in Jamaica, Environmental Entomology, 32: 499-509, 2003.

doi: 10.1603/0046-225X-32.3.499

[16] Blackman RL, Eastop VF. Aphids on the World's Crops: An Identification and Information Guide. 2nd ed. John Wiley and Sons Ltd, Chichester, UK, 2000. 
[17] Folmer O, Black M, Hoeh W, Lutz R. DNA primers for amplification of mitochondrial cytochrome c oxidase subunit I from diverse metazoan invertebrates, Molecular Marine Biology and Biotechnology, 3: 294-299, 1994.

[18] Duque-Gamboa DN, Castillo-Cárdenas MF, Hernández LM, Guzmán,YC, Manzano MR, Toro-Perea N. Mitochondrial DNA suggests cryptic speciation in Prodiplosis longifila Gagné (Diptera: Cecidomyiidae) associated with geographic distance and host specialization, Bulletin of Entomological Research, 108: 739-749, 2018.

doi: $10.1017 /$ S0007485317001298

[19] Tamura K, Stecher G, Peterson D, Filipski A, Kumar S. MEGA6: molecular evolutionary genetics analysis version 6.0, Molecular Biology and Evolution, 30: 2725-2729, 2013.

doi: 10.1093/molbev/mst197

[20] Hebert PDN, Cywinska A, Ball SL. Biological identifications through DNA barcodes, Proceedings of the Royal Society of London B: Biological Sciences, 270: 313-321, 2003.

doi: $10.1098 /$ rspb.2002.2218

[21] van Velzen R, Weitschek E, Felici G, Bakker FT. DNA barcoding of recently diverged species: Relative performance of matching methods, PloS One, 7: 304-309, 2012.

doi: 10.1371/journal.pone.0030490

[22] Ratnasingham S, Hebert PDN. BOLD: The barcode of life data system, Molecular Ecology Notes, 7: 355-364, 2007.

doi: 10.1111/j.1471-8286.2007.01678.x

[23] Carey JR. Applied demography for biologists with special emphasis on insects. 1st ed. U niversity Press, Oxford, UK, 1993. doi: 10.1016/0169-5347(94)90043-4

[24] R Core Team R: A language and environment for statistical computing. R Foundation for Statistical Computing, Vienna, Austria, 2018.

Retrieved from https://www.r-project.org/ 
[25] Özgökçe MS, ChiH, Atlıhan R, Kara H. Demography and population projection of Myzus persicae (Sulz.) (Hemiptera: Aphididae) on five pepper (Capsicum annuum L.) cultivars, Phytoparasitica, 46: 153-167, 2018.

doi: $10.1007 /$ s12600-018-0651-0

[26] Amaral D, VenzonM, dos Santos H, Sujii ER, Schmidt JM, Harwood JD. Non-crop plant communities conserve spider populations in chili pepper agroecosystems, Biological Control, 103: 69-77, 2016.

doi: 10.1016/j.biocontrol.2016.07.007

[27] Dixon AFG, Kindlmann P, Leps J, Holman J. Why there are so few species of aphids, especially in the tropics, The American Naturalist, 129: 580-592, 1987.

doi: 10.1086/284659

[28] Duffy C, Fealy R, Fealy RM. An improved simulation model to describe the temperature-dependent population dynamics of the grain aphid, Sitobion avenae, Ecological Modelling, 354: 140-171, 2017. doi: 10.1016/j.ecolmodel.2017.03.011

[29] Rodriguez N, Michelotto MD, Da Silva RA, Busoli AC. Nymphal development of Myzus persicae (Sulzer, 1776) (Hemiptera: Aphididae) on eggplant at different temperatures, Bragantia, 64: 257-262, 2005.

doi: 10.1590/S0006-87052005000200013

[30] Hazell S, Groutides C, Neve B, Blackburn T, Bale J. A comparison of low temperature tolerance traits between closely related aphids from the tropics, temperate zone, and Arctic, Journal of Insect Physiology, 56: 115-122, 2010.

doi: 10.1016/j.jinsphys.2009.08.020

[31] Kersting U, Satar S, Uygun N. Effect of temperature on development rate and fecundity of apterous Aphis gossypii Glover (Hom., Aphididae) reared on Gossypium hirsutum L, Journal of Applied Entomology, 123: 23-27, 1999.

doi: 10.1046/j.1439-0418.1999.00309.x

[32] da Costa JG, Pires EV, Riffel A, Birkett MA, Bleicher E, Sant'Ana AEG. Differential preference of Capsicum spp. cultivars by Aphis gossypii is conferred by variation in volatile semiochemistry, Euphytica, 177: 299-307, 2011.

doi: 10.1007/s10681-010-0250-8 
[33] Özder N, Sağlam Ö. The effects of temperature for development time, fecundity and reproduction on some ornamental aphid species, Journal of Central European Agriculture, 14: 627-635, 2013.

doi: 10.5513/JCEA01/14.2.1243

[34] Razmjou J, Moharramipour S, Fathipour Y, Seyed S. Effect of cotton cultivar on performance of Aphis gossypii (Homoptera: Aphididae) in Iran, Journal of Economic Entomology, 99: 18201825, 2006.

doi: $10.1093 /$ jee/99.5.1820

[35] Madahi K, Sahragard A, Hosseini R, Baniameri V. Life history performance of Aphis gossypii (Hemiptera: Aphididae) on six different host plants under microcosm condition, Journal of Entomological Society of Iran, 38: 151-172, 2018.

doi: $10.22117 /$ jesi.2018.121466.1216

[36] Jaquiéry J, Stoeckel S, Larose C, Nouhaud P, Rispe C, Mieuzet L, Bonhomme J, Mahéo F, Legeai F, Gauthier J-P, PrunierLeterme N, Tagu D, Simon J-C. Genetic control of contagious asexuality in the pea aphid, PLoS Genetics, 10: 1-10, 2014.

doi: 10.1371/journal.pgen.1004838

[37] Barbosa LR, Carvalho CF, Auad AM, de Souza, B, Batista EP. Tabelas de esperança de vida e fertilidade de Myzus persicae sobre pimentão em laboratório e casa de vegetação, Bragantia, Campinas, 70: 375-382, 2011.

doi: 10.1590/s0006-87052011000200018

[38] Abdel-Salam AH, Ghanim AA, Hala AKE-S, El-Heneidy AH, Mervat KE-S. Biological and life table parameters of Myzus persicae (Sulz.) (Hemiptera: Aphididae) in relation to host plants and thermal requirements, Mansoura University Journal of Agricultural Sciences, 34: 8251-8262, 2009.

[39] Brault V, Uzest M, Monsion B, Jacquot E, Blanc S. Aphids as transport devices for plant viruses, Comptes Rendus Biologies, 333(6-7): 524-538, 2010.

doi: 10.1016/j.crvi.2010.04.001

[40] Singh K, Singh, R. Effect of temperature on the life history traits of Aphis gossypii Glover (Homoptera: Aphididae) on bottle gourd, Laginaria siceraria (Molina) Standl. (Cucurbitaceae), International Journal of Life Sciences Biotechnology and Pharma Research, 4: 179-183, 2015. 
[41] Satar S, Kersting U, Uygun N. Effect of temperature on population parameters of Aphis gossypii Glover and Myzus persicae (Sulzer)(Homoptera: Aphididae) on pepper, Journal for Plant Diseases and Plant Protection, 115: 69-74, 2008.

doi: $10.1007 / \mathrm{BF} 03356241$

[42] Yin-jun F, Fen L, Abd Allah MAH, Xiao-qin Y, Min Z, Nicolas D, Xi-wu G. The damage risk evaluation of Aphis gossypii on wheat by host shift and fitness comparison in wheat and cotton, Journal of Integrative Agriculture, 17: 631-639, 2018.

doi: 10.1016/S2095-3119(17)61784-2

[43] Denno RF, McClure MS, Ott JR. Interspecific interactions in phytophagous insects: Competition reexamined and resurrected, Annual Review of Entomology, 40: 297-331, 1995.

doi: 10.1146/annurev.en.40.010195.001501

[44] Guerrieri E, Digilio MC. Aphid-plant interactions: A review, Journal of Plant Interactions, 3: 223-232, 2008.

doi: 10.1080/17429140802567173

[45] Caballero-López B, Bommarco R, Blanco-Moreno JM, Sans FX, Pujade-Villar J, Rundlöf M, Smith HG. Aphids and their natural enemies are differently affected by habitat features at local and landscape scales, Biological Control, 63: 222-229, 2012.

doi: 10.1016/j.biocontrol.2012.03.012

[46] Cui L, Qi H, Yang D, Yuan H Rui C. Cycloxaprid : A novel cisnitromethylene neonicotinoid insecticide to control imidaclopridresistant cotton aphid (Aphis gossypir), Pesticide Biochemistry and Physiology, 132: 1-6, 2016.

doi: $10.1016 /$ j.pestbp.2016.02.005

[47] Zhou K, Huang J, Deng X, van der Werf W, Zhang W, Lu Y, Wu K, Wu F. Effects of land use and insecticides on natural enemies of aphids in cotton: First evidence from smallholder agriculture in the North China Plain, Agriculture, Ecosystems \& Environment, 183: 176-184, 2014.

doi: 10.1016/J.AGEE.2013.11.008

[48] Ali A, Desneux N, Lu Y, Wu K. Key aphid natural enemies showing positive effects on wheat yield through biocontrol services in northern China. Agriculture, Ecosystems \& Environment, 266: 1-9, 2018.

doi: 10.1016/j.agee.2018.07.012 


\section{Identificación e historia de vida de áfidos asociados con cultivos de chile en el suroeste colombiano}

Resumen: Las enfermedades virales transmitidas por áfidos son uno de los problemas más limitantes en los cultivos de chile. La comprensión de las características demográficas de estos áfidos puede contribuir al diseño de mejores estrategias de control en el chile. Las especies de áfidos que se encuentran en cultivos de chile en el suroccidente colombiano fueron identificadas como Aphis gossypii Glover y Myzus persicae (Sulzer). Se investigó un conjunto de parámetros de la historia de vida de ambas especies a $25{ }^{\circ} \mathrm{C} \pm 0.5,75 \pm 1.75 \%$ r.h., L12:D12, y LS 5-Light Storm en cultivos de chile. Ambas poblaciones de áfidos estaban compuestas únicamente de hembras partenogenéticas, y mostraban un tiempo de desarrollo promedio similar - del primer estadio ninfal al adulto post-reproductivo-, así como de longevidad de las hembras y de valores promedio diarios de fertilidad. La longitud del periodo reproductivo fue mayor para $M$. persicae. A. gossypii alcanzó su estado adulto significativamente más rápido que $M$. persicae. La tasa intrínseca de crecimiento poblacional $\left(r_{m}\right)$ fue menor para $M$. persicae (0.39) comparada con $A$. gossypii (0.43). Los resultados mostraron el potencial de crecimiento rápido de ambas especies, lo cual potencia su papel como vectores de virus. La información adquirida es esencial para desarrollar iniciativas de manejo de pestes para estas dos especies de áfidos.

Palabras clave: Aphis gossypii, código de barras, Capsicum, Myzus persicae, valores $r_{m}$. 


\section{Identificação e história de vida de pulgóes associados a plantaçóes de pimenta no sudoeste da Colômbia}

Resumo: As doenças virais transmitidas por pulgões são um dos problemas mais limitantes nos cultivos de pimenta. O entendimento das características demográficas de estes pulgões pode contribuir ao desenho de melhores estratégias de controle em pimenta. As espécies de pulgões que se encontram em cultivos de pimenta no sudoeste da Colômbia foram identificadas como Aphis gossypii Glover e Myzus persicae (Sulzer). Foi investigado um conjunto de parâmetros da historia de vida de ambas espécies a $25{ }^{\circ} \mathrm{C} \pm 0,5,75 \pm 1,75 \%$ H.R, L12:D12, e LS 5-Light Storm em culturas de pimenta. Ambas populações de pulgões estavam constituídos unicamente de fêmeas partenogenéticas e mostravam um tempo médio de desenvolvimento similar -desde o primeiro estágio ninfal até o adulto pós-reprodutivo-, longevidade da fêmea e valores diários médios de fertilidade. A duração do período reprodutivo foi maior para $M$. persicae. A. gossypii alcançou seu estado adulto significativamente mais rápido que $M$. persicae. A taxa intrínseca do crescimento populacional $\left(r_{m}\right)$ foi menor para $M$. persicae $(0,39)$ comparada com $A$. gossypii $(0,43)$. Os resultados mostraram o potencial de rápido crescimento de ambas espécies, o qual pode ampliar seu papel como vetores virais. A informação adquirida é essencial para desenvolver iniciativas de controle de pestes para estas duas espécies de pulgões.

Palavras-chave: Aphis gossypii, código de barras, Capsicum, Myzus persicae, valores $r_{m}$. 


\section{William Talaga Taquinas}

Is an agricultural engineer from the Universidad Nacional de Colombia in Palmira who follows his MSc studies on Agricultural Sciences at the same institution. His research focuses on taxonomy and ecology of aphids and their role as virus vectors. He also does research about pest monitoring, pest insect spatial modeling and IPM on orchards and vegetable crops.

\section{Clara Inés Melo Cerón}

Is an agroforestry engineer from the Universidad de Nariño, Colombia. She finished her MSc studies on Agricultural Sciences at the Universidad Nacional de Colombia in Palmira and she follows her PhD studies on Agroecology at the same institution. Her research focuses on ecology, biological control and community structure of aphids and their natural enemies on chili pepper crops. Also she has been involved in research about biofertilization and agroforestry.

\section{Yorley Lagos Alvarez}

Is an agricultural engineer from the Universidad Nacional de Colombia in Palmira who follows her MSc studies on Agricultural Sciences at the same institution. Currently is a Visiting Researcher at the International Center of Tropical Agriculture (CIAT) in Cali, Colombia. Her research focuses on the evaluation of pesticide residues on Rubus glaucus fruits in Valle del Cauca, Colombia.

\section{Diana Nataly Duque Gamboa}

Is a biologist from the Universidad del Valle. She finished her MSc studies at the Universidad del Valle and currently follows her $\mathrm{PhD}$ studies on Biology (Sciences) at the same institution. Her research focuses on the use of molecular tools to identify pest insects, to determine virus presence on both plants and insects and also to characterize trophic interactions in biological control of pest insects. 


\section{Nelson Toro-Perea}

Is a molecular biologist. He is currently an associate professor at the Universidad del Valle in Cali, Colombia. His research interest is focused on the use of molecular tools to know and characterize the evolutionary patterns of species in the neotropics, as well as the interactions between plants and their associated organisms, such as symbionts and pathogens.

\section{Maria R. Manzano}

Is a biologist and entomologist with graduated studies on crop protection and biological control of pest insects. Much of her work is collaborative, her research program is broad, combining biology, taxonomy and ecology of insects to develop basic knowledge that support both, the development of biological control and the integrated pest management (IPM) programs. 